\title{
OBAVEŠTAVANJE O STICANJU I RASPOLAGANJU ZNAČAJNIM UČEŠĆEM
}

\begin{abstract}
Milena MITROVIĆ*
Apstrakt: Autor se u radu bavi objavljivanjem značajnog učešća u društvu. Analizirane su odredbe Direktive o transparentnosti i dosadašnji tok harmonizacije u ovoj oblasti. Posebno su razmotrena pitanja nastanka obaveze izveštavanja i potreba da se prilikom regulisanja nastanka obaveze obaveštavanja o dostizanju, prelasku ili padu ispod relevantnog praga učešća uzmu u obzir različiti finansijski instrumenti i transakcije koji mogu omogućiti uticaj na upravljanje društvom. Ukazano je na nedoumice i probleme koji se javljaju u vezi sa primenom postojećih rešenja. Istaknuto je da postoji potreba da regulatori stalno imaju u vidu inovativnost na finansijskom tržištu, kako bi na adekvatan način odgovorili na potrebu da se identifikuju ona lica koja zaista mogu imati uticaj na odlučivanje društva. Pritom, prava mera obaveštavanja je ključna, jer se u suprotnom tržište može preopteretiti informacijama. Pored toga, prostor za unapređenje rešenja postoji i u odnosu na sankcionisanje povrede obaveze obaveštavanja.

Ključne reči: značajno učešće, finansijski instrumenti, sticanje i raspolaganje značajnim učešćem, objavljivanje informacija, prazno glasanje, skriveno vlasništvo
\end{abstract}

\section{1) UVOD}

Objavljivanje informacija na tržištu kapitala predstavlja jedan od glavnih mehanizama prevazilaženja asimetrije informacija. Bez objavljivanja informacija bilo bi nemoguće donošenje informisanih investicionih odluka. Društva danas

\footnotetext{
* Istraživač pripravnik, Institut za međunarodnu politiku i privredu, milena.mitrovic@diplomacy.bg.ac.rs.
}

Rad je nastao u okviru naučnoistraživačkog projekta „Srbija i izazovi u međunarodnim odnosima 2021. godine", koji finansira Ministarstvo prosvete, nauke i tehnološkog razvoja Republike Srbije, a realizuje Institut za međunarodnu politiku i privredu tokom 2021. godine. 
objavljuju veliki broj informacija finansijskog i nefinansijskog karaktera. Jedna od obaveza objavljivanja odnosi se na objavljivanje sticanja i raspolaganja značajnim učešćem. Izražena je potreba objavljivanja tih informacija, budući da su podaci o tome koja lica imaju uticaj na odlučivanje u društvu od velikog značaja ne samo za buduće, već i postojeće ulagače, upravu društva, nadzorne organe i sva druga zainteresovana lica. Ipak, ova pravila su praćena brojnim nedoumicama i dilemama, naročito usled činjenice da su mnoge države na različite načine uredile obavezu objavljivanja. Trenutno stanje je dodatno zakomplikovala činjenica da je finansijska inovativnost na tržištu dovela do toga da postoje različiti instrumenti koji mogu imati slične efekte kao i sticanje akcija s pravom glasa, a preko kojih je moguće uticati na proces donošenja odluka u društvu. Problemi su se javili i u odnosu na adekvatno sankcionisanje povrede obaveze izveštavanja, pa je jedan od ciljeva i uspostavljanje efikasnijih mehanizama sankcionisanja.

Cilj rada je da predstavi režim obaveštavanja o sticanju značajnog učešća. Nakon uvodnog izlaganja o regulatornom konceptu i ciljevima obaveštavanja, sledi deo u kojem je razmotreno pitanje nastanka obaveze izveštavanja, uz analizu propisanih relevantnih pragova, finansijskih instrumenata obuhvaćenih obavezom i računanja pragova. Ta pitanja su od ključne važnosti za objavljivanje, naročito jer su ona tokom poslednjih godina bila među najproblematičnijim odredbama. Zatim su izloženi izuzeci od obaveze izveštavanja i procedura izveštavanja. Nakon toga, kratko je razmotreno pitanje sankcionisanja povreda obaveze izveštavanja, koje u poslednje vreme izaziva dosta pažnje usled toga što to pitanje i dalje nije harmonizovano u dovoljnoj meri.

\section{2) REGULATORNI KONCEPT I RAZLOZI REGULISANJA OBAVEŠTAVANJA}

Objavljivanje o raspolaganju značajnim učešćem predstavlja važan deo povremenog obaveštavanja u vezi sa aktivnostima javnih društava. 0 velikom značaju informacija o promenama u kapital učešću, između ostalog, govori i činjenica da je još 1988. godine doneta direktiva koja je regulisala pitanje obelodanjivanja raspolaganja (značajnim) kapital učešćem. ${ }^{1}$ Obaveza obaveštavanja je sada regulisana Direktivom o transparentnosti, koja predviđa da je lice (pravno i fizičko) koje stekne ili otuđi značajno učešće u društvu obavezno da obavesti društvo i javnost o takvim promenama. ${ }^{2}$ Važno je istaći da su Direktivom o transparentnosti

1 "Council Directive 88/627/EEC of 12 December 1988 on the information to be published when a major holding in a listed company is acquired or disposed of", OJ L 348, 15.11.2014.

2 "Directive 2013/50/EU of the European Parliament and of the Council of 22 October 2013 amending Directive 2004/109/EC of the European Parliament and of the Council on the harmonisation of transparency requirements in relation to information about issuers whose 
obuhvaćeni samo izdavaoci čijim se hartijama od vrednosti trguje na regulisanom, a ne i na drugim organizovanim tržištima. ${ }^{3}$ Takav pristup se može kritikovati budući da nije zanemarljiv značaj aktivnosti koje se odvijaju van regulisanog tržišta prvenstveno na MTP tržištu (Multilateral Trading Facility). S druge strane, izjednačavanje tretmana trgovine na regulisanom i drugim organizovanim tržištima dovelo bi do toga da se umanje komparativne prednosti opredeljivanja društava da uključuju svoje hartije od vrednosti u trgovinu na vanberzanskom organizovanom tržištu, vodeći se prvenstveno manjim troškovima i blažim obavezama za javna društva. ${ }^{4}$ Stoga, potrebno je pažljivo proceniti da li je u ovom trenutku poželjno da se obavežu i društva čijim se hartijama od vrednosti trguje na vanberzanskom organizovanom tržištu, naročito ukoliko se uzme u obzir nastojanje EU da se podstakne konkurencija između regulisanog tržišta i alternativnih načina trgovine kako bi se umanjio svojevrsni "monopol” regulisanih tržišta. ${ }^{5}$

Obaveza objavljivanja je u više navrata bila predmet reformi u pravu EU. Posebno je bilo problematično što su postojale značajne razlike u pogledu regulisanja obaveštavanja o raspolaganju značajnim učešćem u državama članicama, naročito kada je reč o pragovima kada obaveza nastaje, o čemu će biti posebno reči. Uz to, postojala je očigledna potreba da se obaveza obaveštavanja proširi i na neke druge finansijske instrumente, a ne samo na akcije s pravom glasa, kao i da se uspostave adekvatni mehanizmi sankcionisanja ukoliko lice ne obavesti o sticanju značajnog učešća u društvu. ${ }^{6}$

securities are admitted to trading on a regulated market, Directive 2003/71/EC of the European Parliament and of the Council on the prospectus to be published when securities are offered to the public or admitted to trading and Commission Directive 2007/14/EC laying down detailed rules for the implementation of certain provisions of Directive 2004/109/EC Text with EEA relevance", OJ L 294, 6.11.2013.

${ }^{3}$ Direktiva o transparentnosti, čl. 2 st. 1 tač. d. Direktiva o transparentnosti za definiciju pojma regulisanog tržišta upućuje na nekadašnju Direktivu o tržištima finansijskim instrumentima koja je zamenjena novom Direktivom o tržištima finansijskim instrumentima (MiFID II), koja sadrži identičnu definiciju kao i ranije važeća direktiva Direktiva o tržištima finansijskim instrumentima. "Directive 2014/65/EU of the European Parliament and of the Council of 15 May 2014 on markets in financial instruments and amending Directive 2002/92/EC and Directive 2011/61/EU (recast) (Text with EEA relevance)Text with EEA relevance", OJ L 173, 12.6.2014.

${ }^{4}$ Detaljnije o uslovima za kotaciju videti: Nebojša Jovanović, Berzansko pravo, Pravni fakultet Univerziteta u Beogradu, Beograd, 2009, str. 282-297.

${ }^{5}$ Više o tome videti: Nebojša Jovanović, „Novi zakonodavni 'mućak' Srbije u MiFID okruženju”, Vuk Radović (ur.), Usklađivanje poslovnog prava Srbije sa pravom Evropske unije (2011), Pravni fakultet Univerziteta u Beogradu, Beograd, 2011, str. 232-245.

${ }^{6}$ Videti: Rüdiger Veil, "The Reform of the Transparency Regime in European Capital Markets Laws", European Company and Financial Law review, Vol. 10, Nr. 1/2013, p. 28; Niamh 
Informacije o raspolaganju značajnim učešćem nisu značajne samo za upravu društva koja na taj način dolazi do informacije koja lica imaju uticaj, odnosno da li postoji eventualna namera da se društvo preuzme, već i za druga lica. Primera radi, investitorima ta informacija može biti osnova za donošenje informisane investicione odluke. Poveriocima je takva informacija takođe od značaja, budući da za poverioce može biti od značaja informacija koje lice ima vlasništvo nad dužnikom i da li postoji potreba za dodatnim sredstvima obezbeđenja. ${ }^{7} \mathrm{U}$ konačnom ishodu, vlasnička struktura može uticati i na vrednost udela u društvu. ${ }^{8}$ Stoga, objavljivanje informacija prevazilazi funkciju zaštite pojedinačnih interesa na tržištu kapitala, već štiti tržište kao celinu. ${ }^{9}$ Iako je takva obaveza u najširem smislu motivisana povećanjem transparentnosti društva, pravne sigurnosti i podsticanja prekograničnog ulaganja, moglo bi se reći da se obaveza obaveštavanja o sticanju ili otuđivanju relevantnog praga učešća usko povezuje sa potrebom identifikacije lica koje (može da) vrši značajan uticaj na upravljanje društvom, na otkrivanje insajderske trgovine i praćenje aktivnosti na tržištu korporativne kontrole.

Kada je reč o identifikaciji lica koje vrši značajan uticaj na odlučivanje, u smislu posedovanja značajnog učešća, ono je povezano sa identifikacijom stvarnih vlasnika, koje je na agendi EU poslednjih nekoliko godina. ${ }^{10}$ Može se postaviti pitanje - koji je smisao obaveze obaveštavanja o sticanju značajnog učešća ukoliko

Moloney, EU Securities and Financial Markets Regulation, Oxford, Oxford University Press, 2014, p. 141; European Commission, Proposal for a Directive of the European Parliament and of the Council amending Directive 2004/109/EC on the harmonisation of transparency requirements in relation to information about issuers whose securities are admitted to trading on a regulated market and Commission Directive 2007/14/EC, COM (2011) 683 final, Brussels, 25.10.2011, p. 5.

${ }^{7}$ Više o tome vidi: Tatjana Jevremović Petrović, „Poverioci u kompanijskom pravu i instrumenti njihove zaštite”, Anali Pravnog fakulteta u Beogradu, br. 1/2011, str. 249-250.

${ }^{8}$ Luca Enriques, Matteo Gargantini, Valerio Novembre, "Mandatory and Contract-based Shareholding Disclosure", 11.4.2011, dostupno na adresi: https://papers.ssrn.com/sol3/ papers.cfm?abstract_id=1807047, 1.4.2021, p. 735; Rüdiger Veil et al., “Today's or Yesterday's News? Eine empirische Analyse von Stimmrechtsmitteilungen gemäß §§ $21 \mathrm{ff}$ WpHG und Schlussfolgerungen für die Kapitalmarktregulierung", ZGR, Nr. 5/2015, pp. 734-735.

${ }^{9}$ Tatjana Jevremović Petrović, „Obavezno objavljivanje kao instrument zaštite poverilaca u kompanijskom pravu", Pravo i privreda, br. 4-6/2011, str. 194.

${ }^{10}$ Videti, primera radi: European Commission, Directive 2017/828/EU of the European Parliament and of the Council of 17 May 2017 amending Directive 2007/36/EC as regards the encouragement of long-term shareholder engagement, OJ L 132, 20. 5. 2017, čl. 2 tač. j, čl. 3a. Napominjemo da u ovom radu neće biti detaljno reči o problemima i potrebama identifikacije stvarnih vlasnika, već samo u meri u kojoj je potrebno da se razume smisao objavljivanja sticanja značajnog učešća (u pravu glasa). 
postoje registri u kojima se nalaze imena akcionara? ${ }^{11}$ Odgovor leži u činjenici da imenovani vlasnik ne mora biti stvarni vlasnik, odnosno ne mora biti lice koje je beneficijar, i koje ima ekonomski interes i snosi rizik ulaganja. To je naročito postao slučaj nakon sprovedene dematerijalizacije hartija od vrednosti. Uz to, tome je doprinelo i angažovanje posrednika koji se pojavljuju kao imenovani vlasnici, pa i čitavog lanca takvih posrednika koji vode do stvarnog vlasnika hartija od vrednosti.

Dva osnovna problema koja se javljaju u vezi sa netransparentnom vlasničkom strukturom su tzv. „skriveno vlasništvo” (eng. hidden ownership) i „prazno glasanje” (eng. empty voting). Prazno glasanje podrazumeva postojanje nesrazmere broja glasova i „ekonomskog vlasništva”, što dovodi do negativnog razdvajanja, dok skriveno vlasništvo podrazumeva suprotno - lice poseduje više ekonomskog vlasništva nego prava glasa, što se naziva i „skrivenim preobražajnim vlasništvom”, budući da lice može manipulisati brojem glasova na način da se ono može pojaviti ili nestati prema potrebi (tzv. pozitivno razdvajanje). ${ }^{12}$ Tradicionalno, koncept vlasništva je trebalo da dovede u sklad vlasnička prava i ekonomsku izloženost, ali je naročito pojava različitih finansijskih derivata narušila takav balans. ${ }^{13}$ Skriveno preobražajno vlasništvo omogućava licu da stekne veliko učešće, a da pritom nije u obavezi da obavesti javnost o tome, što se postiže korišćenjem različitih finansijskih instrumenata i poslova. ${ }^{14}$ Značajan problem u vezi sa identifikacijom stvarnih vlasnika, stoga, predstavlja okolnost da pravila o identifikaciji stvarnih vlasnika najčešće nisu u mogućnosti da odgovore na problem korišćenja različitih finansijskih derivata, koji takođe mogu da budu sredstvo preuzimanja društva i sticanja kontrole. ${ }^{15}$ Suština identifikacije stvarnih vlasnika je, dakle, da se odgovori na pitanje

${ }^{11}$ Paul L. Davies, Sarah Worthington, Gower Principles of Modern Company Law, Sweet \& Maxwell, Thomson Reuters, London, 2016, p. 875.

${ }^{12}$ Luca Enriques, Matteo Gargantini, Valerio Novembre, "Mandatory and Contract-based Shareholding Disclosure”, op. cit., p. 721; Jelena Lepetić, „Aktivizam akcionara”, Pravo i privreda, br. 10-12/2018, str. 118.

${ }^{13}$ Marten Knuts, "The Disclosure of Cash Settled Equity Derivatives. Will the Proposed Amendments Solve the Problems", in Holger Fleischer, Jesper Lau Hansen, Wolf-Georg Ringe (eds.), German and Nordic Perspectives on Company Law and Capital Markets Law, Mohr Siebeck, Tübingen, 2015, p. 238.

${ }^{14}$ Klaas Vanneste, "Decoupling Economic Rights from Voting Rights: A Threat to the Traditional Corporate Governance Paradigm", European Business Organization Law Review, Nr. 1/2014, p. 72; Christine Osterloh-Konrad, "Gefährdet 'Empty Voting' die Willensbildung in der Aktiengesellschaft? Überlegungen zur Proportionalität zwischen Stimmrechtseinfluss und wirtschaftlicher Betroffenheit der Aktionäre", ZGR, Nr. 1/2012, p. 44.

${ }^{15}$ Peter Böckli et al., "Shareholder Engagement and Identification", dostupno na adresi: https://papers.ssrn.com/sol3/papers.cfm?abstract_id=2568741, 10.5.2021, internet izvor bez broja strane. 
koje lice snosi ekonomski rizik poslovanja, odnosno ko je zapravo beneficijar. ${ }^{16} \mathrm{~S}$ druge strane, kada je reč o objavljivanju raspolaganja značajnim učešćem (u pravu glasa), suština je odgovoriti na pitanje koje lice ima stvarnu, odnosno potencijalnu kontrolu nad društvom. ${ }^{17}$ Međutim, identifikacija stvarnih vlasnika podrazumeva preduzimanje radnji da bi se vlasnik identifikovao bez obzira na to koliki je njegov udeo, dok to nije slučaj sa pravilima o objavljivanju značajnog kapital učešća. ${ }^{18}$

Promene u kapital učešću, odnosno u pravu glasa, mogu biti i signal da je došlo do insajderske trgovine, odnosno zloupotrebe insajderskih informacija, iako je ta funkcija u manjoj meri primarna u Direktivi o transparentnosti, budući da je to pitanje detaljnije uređeno Uredbom o sprečavanju tržišnih manipulacija. ${ }^{19} \mathrm{U}$ svakom slučaju, situacija u kojima je lice pribavilo ili otuđilo značajno učešće u društvu može biti upozoravajuće za upravu društva, regulatore i druga zainteresovana lica na tržištu da je došlo do upotrebe insajderskih informacija.

Očigledna je veza objavljivanja sticanja značajnog učešća sa nadzorom nad tržištem korporativne kontrole, jer mogu ukazati na potencijalno preuzimanje i uopšte strukturu tržišta korporativne kontrole. ${ }^{20}$ Iako je preuzimanje uređeno posebnim propisom - Direktivom o preuzimanju, odredbe Direktive o transparentnosti mogu biti značajne. Zapravo, nastanak pravila o obaveštavanju o sticanju značajnog učešća se upravo vezuje za slučajeve neprijateljskih preuzimanja. Ukoliko neko lice postepeno stiče značajno učešće, ta činjenica bi trebalo da bude vidljiva za upravu društva, koje je tada u prilici da preduzme dozvoljene mere odbrane, ${ }^{21}$ ali i za aktiviranje brojnih pravila koja imaju za cilj da obezbede zaštitu interesa akcionara, zaposlenih, društva i drugih zainteresovanih lica u postupku preuzimanja. ${ }^{22}$ Zbog toga se u nekim pravima dodatno zahteva da lice koje stekne

\footnotetext{
${ }^{16}$ Investitor se tako najčešće definiše kao lice koje snosi ekonomski rizik ulaganja. Vidi: Mirjana Radović, „Zakoniti imalac dematerijalizovanih hartija od vrednosti”, Pravo i privreda, br. 46/2011, str. 652.

${ }^{17}$ Paul L. Davies, Sarah Worthington, Gower Principles of Modern Company Law, op. cit., p. 875.

${ }^{18}$ Luca Enriques, Matteo Gargantini, Valerio Novembre, "Mandatory and Contract-based Shareholding Disclosure", op. cit., p. 718.

${ }^{19}$ Michael C. Schouten, "The Case for Mandatory Ownership Disclosure", dostupno na adresi: https://ssrn.com/abstract=1327114, p. 22.

${ }^{20}$ Niamh Moloney, EU Securities and Financial Markets Regulation, op. cit., p. 140. U ovom radu će se razmatranje ograničiti na dužnost izveštavanja o promenama učešća u kontekstu Direktive o transparentnosti, te o preuzimanju neće biti reči detaljnije. Detaljnije o preuzimanju videti: Vuk Radović, Mere odbrane akcionarskog društva od preuzimanja kontrole, doktorska disertacija, Pravni fakultet Univerziteta u Beogradu, Beograd, 2007.

${ }^{21}$ Detaljno o merama odbrane videti, Vuk Radović, op. cit.

${ }^{22}$ Vidi: Luca Enriques, Matteo Gargantini, Valerio Novembre, "Mandatory and Contract-based Shareholding Disclosure", op. cit., p. 731.
} 
određeni prag (po pravilu 10\% ili više) obavesti izdavaoca o cilju sticanja takvog učešća, kao i o eventualnim promenama namere. ${ }^{23}$ Sticanje učešća od 10 ili više procenata vlasništva je po pravilu motivisano sticanjem kontrole u društvu. ${ }^{24}$

\section{3) NASTANAK OBAVEZE OBAVEŠTAVANJA}

Nastanak obaveze objavljivanja nastaje ukoliko lice dostigne, pređe ili padne ispod propisanog praga učešća. Pritom, osnov takve promene je irelevantan - do promena može doći ne samo kao posledica namere lica da do takve promene dođe, već i spletom različitih okolnosti nastalih nezavisno od volje lica, koje u krajnjem ishodu dovode do promene u udelu u glasačkim pravima. ${ }^{25}$ Tako dolazi u obzir ne samo, primera radi, prodaja i kupovina udela od strane ulagača, već i nasleđivanje, pozajmljivanje, sticanje sopstvenih akcija od strane društva i sl. ${ }^{26}$ Ipak, s obzirom na dinamičnost tržišta i brojnih transakcija koje se obavljaju na dnevnom nivou, potrebu da se uzme u obzir da izveštavanje prate troškovi, potrebno je jasno precizirati kada takva obaveza nastaje. Time se ujedno izbegava da se zainteresovana lica i tržište preopterete informacijama, što u konačnom ishodu može dovesti do neefikasne alokacije resursa umesto da se poboljša transparentnost tržišta i alokacija resursa. Stoga će u narednom delu biti detaljnije reči o relevantnim pragovima i finansijskim instrumentima koji su obuhvaćeni.

\subsection{RELEVANTNI PRAGOVI}

Pitanje postavljanja relevantnih pragova bilo je jedno od najspornijih pitanja $u$ vezi sa primenom Direktive o transparentnosti. Kroz različite verzije Direktive o transparentnosti može se uočiti tendencija dodavanja pragova. ${ }^{27}$ Direktiva 0 transparentnosti iz 1988. godine izričito je ovlastila države članice da unesu

\footnotetext{
${ }^{23}$ Vidi: Wertpapierhandelsgesetz - WpHG, dostupno na adresi: https://www.gesetze-iminternet.de/wphg/WpHG.pdf, 2.5.2021, čl. 43.

${ }^{24}$ Tatjana Jevremović Petrović, Grupe privrednih društava, Pravni fakultet Univerziteta u Beogradu, Beograd, 2014, str. 103.

${ }^{25}$ Konstantinos Sergakis, The Law of Capital Markets in the EU: Disclosure and Enforcement, Palgrave, London, 2018, p. 122; Stefan Grundmann, European Company Law: Organization, Finance and Capital Markets, Intersentia, Cambridge-Antwerp-Portland, 2016, p. 520.

${ }^{26}$ Stefan Grundmann, European Company Law: Organization, Finance and Capital Markets, op. cit., p. 520.

${ }^{27}$ U Direktivi o objavljivanju informacija u slučaju raspolaganja značajnim kapital učešćem iz 1998. godine pragovi su bili: $10 \%, 20 \%, 1 / 3,50 \%$ i $2 / 3$ (čl. 4). Direktiva o transparentnosti iz 2004. godine unela je izmene, te su predviđeni pragovi od 5\%, 15\%, 20\% i 30\% uz postojeće. Država prijema nije ovlašćena da unosi strože zahteve u pogledu obaveštavanja, dok država porekla jeste. Vidi: Direktiva o transparentnosti, čl. 3 i 9.
} 
dodatne pragove, dok je Direktiva iz 2004. godine usvojila kombinovan pristup država prijema je mogla da predvidi strožu obavezu. ${ }^{28} \mathrm{~S}$ obzirom na okolnost da su ranije verzije Direktive o transparentnosti imale za cilj minimalnu harmonizaciju, države članice su postavljale različite pragove, uglavnom tako što su dodavale pragove. Takva situacija je sa aspekta pravne sigurnosti, unapređenja transparentnosti i podsticanja prekograničnih aktivnosti nepoželjna.

Na različitost pragova naročito je uticala činjenica da različita tržišta odlikuje različit stepen disperzovanosti vlasništva, ali i potreba da se kontroliše preuzimanje društava. ${ }^{29} \mathrm{U}$ državama gde je zastupljeno koncentrisano vlasništvo, postavljanje suviše niskih pragova ne bi bilo previše smisleno jer se tu uglavnom i ne radi o promeni lica koje odlučujuće utiče na upravljanje društva. Suprotno tome, ukoliko je vlasništvo u većoj meri disperzovano, značajan uticaj može da vrši i lice koje ima manji procenat učešća, pa je opravdano postaviti niže pragove. ${ }^{30}$ Naravno, brojni drugi faktori pored disperzovanosti su od značaja kada je reč o tome koje lice vrši uticaj na upravljanje društvom - primera radi, stepen prisutnosti na sednicama skupština, postojanje ugovora koji omogućavaju uticaj na upravljanje društvom (poput ugovora o kontroli i upravljanju) i druge okolnosti mogu biti relevantni. ${ }^{31} \mathrm{~S}$ jedne strane, smisleno je omogućiti prilagođavanje pragova konkretnim okolnostima, odnosno nema mesta odredbama koje se jednako primenjuju na sva društva dok, s druge strane, postoje argumenti u prilog tome da ipak treba imati u vidu strukturu celokupnog tržišta, a ne pojedinačnog društva. ${ }^{32}$

Pristup usvojen u Direktivi o transparentnosti je negde „na pola puta”. Predviđeni su pragovi od 5\%, 10\%, 15\%, 20\%, 25\%, 30\%, 50\% i 75\% učešća u pravu glasa u društvu čijim se akcijama trguje na regulisanom tržištu. ${ }^{33}$ Zabranjeno je postavljanje strožih uslova u pogledu izračunavanja pragova, agregacije udela

\footnotetext{
${ }^{28}$ Više o tome videti: Holger Fleischer, Klaus Ulrich Schmolke, "The Reform of the Transparency Directive: Minimum or Full Harmonisation of Ownership Disclosure", European Business Organization Law Review, Nr. 1/2011, pp. 125-126.

${ }^{29}$ Rüdiger Veil, "The Reform of the Transparency Regime in European Capital Markets Laws", op. cit., p. 31.

${ }^{30}$ Videti i: European Commission, Proposal for a Directive of the European Parliament and of the Council amending Directive 2004/109/EC on the harmonisation of transparency requirements in relation to information about issuers whose securities are admitted to trading on a regulated market and Commission Directive 2007/14/EC, COM (2011) 683 final, Brussels, 25. 10. 2011, pp. 6-7.

${ }^{31}$ Detaljno o kontroli, vidi: Tatjana Jevremović Petrović, Grupe privrednih društava, op. cit., str. 80-118.

${ }^{32}$ Luca Enriques, Matteo Gargantini, Valerio Novembre, "Mandatory and Contract-based Shareholding Disclosure", op. cit., p. 735.

${ }^{33}$ Direktiva o transparentnosti, čl. 9.
} 
glasačkih prava koja se odnosi na finansijske instrumente i izuzetke od obaveze izveštavanja. Međutim, dozvoljeno je da države članice prilikom implementacije rešenja uzmu u obzir koncentrisanost vlasništva. ESMA (European Securities Markets Authority) je 2018. godine objavila priručnik u kojem je dat pregled nacionalnih rešenja država Evropske ekonomske zone - EEA (European Economic Area). Najveći broj država članica EEA (24, odnosno 25 ako se uzme u obzir specifično rešenje Velike Britanije čiji su propisi usklađeni kada je reč o stranim izdavaocima, ali se domaćim izdavaocima nameću dodatni zahtevi) iskoristile su mogućnost $i$ unele dodatne pragove, pri čemu je to po pravilu bilo dodavanje praga o obaveštavanju kada lice dostigne, pređe ili padne ispod $90 \%$, ali nije bio redak slučaj ni da države dodaju procente koji su niži od $5 \%{ }^{34}$

Prema tome, dozvoljeno je da države članice: 1) predvide niže ili dodatne pragove; 2) da postave strože zahteve u pogledu procedure izveštavanja, ili 3) prilikom primene zakona, uredbi, ili administrativnih propisa usvojenih za svrhe preuzimanja, spajanja ili drugih transakcija koje utiču na vlasničku strukturu ili kontrolu društva. ${ }^{35}$ Ovaj poslednji izuzetak je prilično široko postavljen i čini se da je ideja bila da se napravi kompromis, odnosno da se omogući da države zadrže neke strože zahteve - primera radi, to je naročito slučaj sa definisanjem zajedničkog delovanja, institut koji su neke države članice naročito razvile s namerom da u ranoj fazi zajedničko delovanje ulagača učine transparentnim. ${ }^{36}$ Dakle, ideja je bila da se opredeljivanjem za maksimalnu harmonizaciju stane na put različitom određivanju pragova, uz razumne izuzetke, budući da je Evropska komisija u više navrata zauzela negativan stav prema slobodi koju su neke države koristile da postavljaju dodatne zahteve (tzv. Gold-plating). ${ }^{37}$ To ipak ne znači da debate o prirodi Direktive o transparentnosti i konačnom opredeljenju za maksimalnu harmonizaciju nisu i danas prisutne, budući da i sama Direktiva na nekoliko mesta daje povod toj raspravi. ${ }^{38}$

\footnotetext{
${ }^{34}$ Za pregled rešenja videti ESMA, Practical Guide - National rules on notifications of major holdings under Transparency Directive, 31 July 2019, dostupno na adresi: https://www.esma. europa.eu/document/practical-guide-notifications-major-holdings-under-transparencydirective, 4. 5. 2021. Samo Hrvatska, Kipar, Grčka, Luksemburg, Slovačka i Slovenija nisu uneli dodatne pragove.

${ }^{35}$ Direktiva o transparentnosti, preambula tač. 12.

${ }^{36}$ Rüdiger Veil, "The Reform of the Transparency Regime in European Capital Markets Laws", op. cit., p. 32.

${ }^{37}$ Holger Fleischer, Klaus Ulrich Schmolke, "The Reform of the Transparency Directive, Minimum or Full Harmonisation of Ownership Disclosure?”, op. cit., p. 129.

${ }^{38}$ Videti naročito: Rüdiger Veil, "The Reform of the Transparency Regime in European Capital Markets Laws", op. cit., pp. 28-35. Primera radi, smatra se da je u materiji sankcija reč o minimalnoj harmonizaciji. Videti: Christoph H. Seibt, Bernward Wollenschläger, "Revision des Europäischen Transparenzregimes: Regelungsinhalte der TRL 2013 und Umsetzungsbedarf", ZIP, Nr. 12/2014, p. 545.
} 


\subsection{FINANSIJSKI INSTRUMENTI OBUHVAĆENI DIREKTIVOM O TRANSPARENTNOSTI I RAČUNANJE PRAGOVA}

Pitanje koje je od jednake, ako ne i veće, važnosti od propisivanja pragova jeste način na koji se dostizanje pragova računa. Ujednačavanje relevantnih pragova nema mnogo smisla ukoliko se ne ujednači i način računanja tih pragova. Upravo se tu vidi možda i najveći prostor za različite zloupotrebe. Od suštinske važnosti jeste i okolnost koji finansijski instrumenti dolaze u obzir prilikom računanja nečijeg učešća.

Najmanje je sporno da se obaveza odnosi na akcije s pravom glasa, budući da smisao pribavljanja učešća uglavnom jeste namera da se glasanjem utiče na postupak odlučivanja u društvu. Glasačka prava će se računati na osnovu svih akcija za koje su vezana glasačka prava, čak i ukoliko je takvo pravo suspendovano. Dodatno, informacija će se dati i za sve akcije u istoj klasi za koje se vezuju glasačka prava ${ }^{39}$ Međutim, treba imati na umu činjenicu da posedovanje akcija s pravom glasa nije jedini instrument koji omogućava vršenje uticaja u društvu. Ukoliko neko lice poseduje finansijske instrumente koji daju pravo da se stekne pravo glasa, ti instrumenti takođe mogu biti sredstvo putem kojeg neko utiče na proces donošenja odluka u društvu. Bilo je slučajeva u kojima su finansijski derivati poslužili kao sredstvo preuzimanja društva. ${ }^{40}$ To je bio povod da se Direktiva o transparentnosti izmeni u pogledu domena primene člana o obaveštavanju o sticanju značajnog kapital učešća, te su predviđeni i drugi slučajevi kada tada obaveza nastaje, a ne samo kada lice stekne akcije sa glasačkim pravom. Obaveza obaveštavanja sada postoji i za pravno i fizičko lice koje drži, direktno ili indirektno: finansijske instrumente koji daju pravo na bezuslovno sticanje ili diskreciono pravo sticanja izdatih akcija sa glasačkim pravom izdavaoca i finansijske instrumente koji imaju sličan ekonomski efekat kao i prethodno navedeni finansijski instrumenti. ${ }^{41}$ Primera radi, u obzir dolaze prenosive hartije od vrednosti, opcije, fjučersi, svopovi, terminski ugovori, diferencijski posao i drugi posao sa sličnim ekonomskim efektima. ${ }^{42}$ Dakle, obuhvatanjem različitih

\footnotetext{
${ }^{39}$ Direktiva o transparentnosti, čl. 9.

${ }^{40}$ Detaljnije o tome videti, primera radi, u: Pierre-Henri Conac, "Cash-Settled Derivatives as a Takeover Instrument and the Reform of the EU Transparency Directive", in Hanne S. Birkmose, Mette Neville, Karsten Engsig Sørensen (eds.), The European Financial Market in Transition, Kluwer Law International BV, 2012, pp. 49-68; Michael C. Schouten, "The Case for Mandatory Ownership Disclosure", dostupno na adresi: https://ssrn.com/abstract=1327114, 5.4.2021, pp. 32-35.

${ }^{41}$ Direktiva o transparentnosti, čl. 13.

${ }^{42}$ Direktiva o transparentnosti, čl. 13 st. 1b. Detaljnije o vrstama poslova vidi: Nebojša Jovanović, Berzansko pravo, op. cit., str. 370-405. ESMA je 2015. godine usvojila indikativnu listu instrumenata na kojoj su se, između ostalog, uz ove finansijske instrumente našle i garancije,
} 
finansijskih instrumenata Direktiva o transparentnosti pokušala je da odgovori na potrebu da transparentno deluju ne samo oni koji vrše kontrolu putem posedovanja akcija s pravom glasa, već da se ta obaveza proširi na one koji na drugi način mogu biti u situaciji da vrše kontrolu i uticaj.

Direktiva o transparentnosti uzima u obzir mogućnost da neko lice vrši pravo glasa i ima uticaj ne samo direktno, već i indirektnim putem. Predviđen je niz situacija u kojima se mora obavestiti javnost da je lice dostiglo, prešlo ili palo ispod propisanog praga. Time su pokriveni slučajevi kada treće lice poseduje glasačka prava po osnovu sporazuma s tim licem, koji ih obavezuju da usvoje zajedničkim vršenjem glasačkih prava trajnu zajedničku politiku u odnosu na upravljanje društvom; treće lice poseduje glasačka prava po osnovu sporazuma kojim je predviđen privremeni prenos tih prava; kada su akcije položene kao zalog ukoliko zalogoprimac kontroliše glasačka prava i izjavi da namerava da ih ostvaruje; pravo glasa u akcijama u kojima lice ima životni interes; pravo glasa (u prethodno navedenim slučajevima) koje poseduje kontrolno društvo; kada su akcije s pravom glasa deponovane, ukoliko to lice može da glasa po svom nahođenju u odsustvu glasačkih instrukcija akcionara; glasačka prava drži treće lice u svoje ime, a za račun tog lica i ukoliko pravo glasa može da ostvari lice kao punomoćnik, i to po svom nahođenju u odsustvu posebnih uputstava akcionara. ${ }^{43}$ Dakle, u tim situacijama se to učešće dodaje učešću lica koje je zapravo u poziciji da koristi pravo glasa.

Iako ova odredba ima za cilj da obuhvati situacije u kojima neko lice drži akcije po različitim osnovima, a pritom može da ostvaruje pravo glasa, čime je trebalo postići veću transparentnost, čini se da su i dalje otvorena neka pitanja. Najpre, to se odnosi na zajedničko delovanje, iako Direktiva o transparentnosti sada pominje slučaj kada su lica zaključila sporazum koji ih obavezuje da usvoje trajnu zajedničku politiku u odnosu na upravljanje društvom. Zajedničko delovanje predstavlja preduzimanje određenih radnji u cilju ostvarivanja zajedničkih interesa lica. Forma, ciljevi i posledice zajedničkog delovanja se razlikuju u zavisnosti od oblasti, pa tako ne postoji jedinstven pojam zajedničkog delovanja. ${ }^{44}$ Direktiva o transparentnosti spominje zaključeni sporazum kao osnov zajedničkog delovanja u smislu vršenja prava glasa. Međutim, u teoriji postoje različiti stavovi u pogledu

ugovori koji daju pravo na ponovni otkup, pravo na opoziv pozajmljenih akcija, ugovorno pravo preče kupovine, drugi uslovni ugovori pored opcija i fjučersa i sl. ESMA, Indicative list of financial instruments, 2015, dostupno na adresi: https://www.esma.europa.eu/document/ indicative-list-financial-instruments, 2.4.2021.

${ }^{43}$ Direktiva o transparetnosti, čl. 10.

${ }^{44}$ Videti: Tatjana Jevremović Petrović, Grupe privrednih društava, op. cit., str. 101. Detaljnije o nejedinstvenom pojmu videti Vuk Radović, „Nejedinstven pojam zajedničkog delovanja”, Vuk Radović (ur.), Usklađivanje poslovnog prava Srbije sa pravom Evropske unije (2019), Pravni fakultet Univerziteta u Beogradu, Beograd, 2019, str. 11-35. 
značenja pojma „sporazum”. S jedne strane, neki smatraju da sporazum mora biti formalan, dok postoje mišljenja da sporazum može biti i neformalan. ${ }^{45}$ Iako formalnost sporazuma olakšava dokazivanje zajedničkog delovanja, opravdano je smatrati da formalan sporazum nije nužan. ${ }^{46}$ Zahtevanje da sporazum bude formalan značajno bi suzio domašaj pravila Direktive o transparentnosti i olakšalo izigravanje pravila. Ovo naročito ako se ima u vidu da je odredba formulisana tako da se odnosi samo na sporazume koji uređuju vršenje glasačkih prava i delovanje na sednicama ${ }^{47}$ Prema tome, nisu obuhvaćeni neki drugi modaliteti zajedničkog delovanja koji za cilj, odnosno posledicu imaju vršenje uticaja na odlučivanje u društvu, iako ne direktno kroz ostvarivanje prava glasa. Ipak, to nije sprečilo neke države članice da prošire pojam zajedničkog delovanja za potrebe izveštavanja o značajnom učešću. Primera radi, u nemačkom pravu se smatra da zajedničko delovanje postoji i kada lica na drugi način sarađuju u cilju vršenja uticaja na poslovanje društva, a ne samo kada postoji sporazum o glasanju. ${ }^{48}$ Važno je istaći da zajedničko delovanje ne treba percipirati kao negativnu pojavu - naprotiv, ono može pospešiti aktivizam manjinskih akcionara koji na taj način mogu da ostvaruju i štite svoja prava, ali je za potrebe transparentnosti potrebno da se takvo delovanje uzme u obzir prilikom računanja pragova. ${ }^{49}$

Osim zajedničkog delovanja, jedno od pitanja koje je i ranije isticano kao problematično, a čini se da to i dalje ostaje zbog različitog tretmana, jeste pozajmljivanje akcija. Iako se spominje sporazum kojim se privremeno prenose glasačka prava, u teoriji je sporno da li su time obuhvaćeni slučajevi kada dolazi do prenosa akcija, a ne samo prava iz akcija - glasačkog prava. ${ }^{50}$ Zajam akcija podrazumeva u većini država članica prenos vlasništva na akciji u slučaju pozajmljivanja. ${ }^{51}$ Neke države, poput Nemačke, Francuske i Engleske, poznaju i dalje akcije na donosioca. Sporno je ko u slučaju pozajmljivanja ima dužnost da obavesti javnost o raspolaganju glasačkim pravom - zajmodavac ili zajmoprimac. S jedne strane, obaveštavanje od strane zajmodavca i zajmoprimca ima smisla utoliko što se na taj način jasno stavlja do znanja ko vrši pravo glasa. S druge strane, učestalost takvih transakcija može dovesti do toga da se objavi previše informacija koje bi

\footnotetext{
${ }^{45}$ Vuk Radović, „Nejedinstven pojam zajedničkog delovanja”, op. cit., str. 20.

${ }^{46}$ Tako i: Tatjana Jevremović Petrović, Grupe privrednih društava, op. cit., str. 100; Vuk Radović, „Nejedinstven pojam zajedničkog delovanja”, op. cit., str. 20-21.

${ }^{47}$ Vuk Radović, Ibid. Detaljnije o ugovorima o glasanju videti Jelena Lepetić, , JJedinstvo članskih prava i ugovori o glasanju akcionara", Pravo i privreda, br. 4-6/2019, str. 225-248.

${ }^{48}$ Wertpapierhandelsgesetz - WpHG, čl. 34 st. 2.

${ }^{49}$ Jelena Lepetić, „Jedinstvo članskih prava i ugovori o glasanju akcionara”, op. cit., str. 234.

${ }^{50}$ Paul L. Davies, Sarah Worthington, Gower Principles of Modern Company Law, op. cit., p. 880.

${ }^{51}$ Mazars, Transparency Directive Assesment Report, 2009, 124
} 
zbunile tržišne učesnike, a pritom ugovor o zajmu akcija poseduje klauzulu po kojoj zajmodavac ima pravo da povrati svoje akcije, zbog čega se smatra da nema suštinskih promena u njegovom položaju. ${ }^{52} \mathrm{U}$ svakom slučaju, ne sme se zanemariti potreba da značajne promene u pogledu promena u posedovanju prava glasa budu transparentne, zbog čega smatramo da bi objavljivanje takvih promena ipak bilo smisleno. Zbog toga je ESMA, u svojoj indikativnoj listi, navela postojanje klauzule o pravu na povraćaj pozajmljenih akcija događaj koji zahteva obaveštavanje. ${ }^{53}$

Može se zaključiti da postoji potreba da se stalno preispituje lista finansijskih instrumenata koji su obuhvaćeni obavezom. Između ostalog, to je prepoznato i u samoj Direktivi o transparentnosti koja je to poverila ESMA-i. ${ }^{54}$ Uzrok tome svakako jeste razvoj tržišta i inovativnost njegovih učesnika. To praktično znači da se mora voditi računa o krajnjem efektu određenih finansijskih instrumenata iz transakcija. Naravno, potrebna je velika opreznost i pažnja, te stalno preispitivanje potreba obaveštavanja, pri čemu se ne sme smetnuti sa uma da je druga krajnost u odnosu na neobjavljivanje zatrpavanje zainteresovanih lica informacijama koje onda oni neće umeti da obrade, da iskoriste u cilju donošenja informisane investicione odluke.

Kada je reč o računanju pragova, Direktiva o transparentnosti je ovlastila ESMA-u da donese pravila o načinu računanja. ESMA je usvojila prilično detaljna pravila o načinu računanja pragova.$^{55} \mathrm{~S}$ druge strane, Direktiva o transparentnosti je samo predvidela da se u obaveštenju raščlanjuju broj glasačkih prava koja lica poseduje na osnovu direktnog i indirektnog držanja, s jedne strane, i glasačka prava u vezi sa drugim finansijskim instrumentima, s druge strane. Ukoliko lice na osnovu tih finansijskih instrumenata stekne akcije i pređe prag, potrebno je dodatno obaveštenje. ${ }^{56}$ Dakle, suština je u tome da se nastoji prikazati celokupno učešće određenog lica u društvu, a ne samo u pravu glasa. Ova odredba, iako ne sadrži previše detalja, ima veliki značaj za ujednačavanje prakse računanja pragova u različitim državama članicama.

\footnotetext{
${ }^{52}$ Paul L. Davies, Sarah Worthington, Gower Principles of Modern Company Law, op. cit., p. 880.

${ }^{53}$ Vid. ESMA Indikativna lista, čl. 3 tač. e.

${ }^{54}$ Vidi: Direktiva o transparentnosti, čl. 13 st. 1 a.

${ }^{55}$ Razmatranje tih metoda prevazilazi obim ovog rada. Za više detalja videti "Commission delegated Regulation (EU) 2015/761 of 17 December 2014 supplementing Directive 2004/109/EC of the European Parliament and of the Council with regard to certain regulatory technical standards on major holdings", OJ L 120/4, 13. 5. 2015.

${ }^{56}$ Direktiva o transparentnosti, čl. 13a.
} 


\section{4) IZUZECI OD OBAVEZE OBJAVLJIVANJA}

Uzevši u obzir učestalost transakcija, ali i potrebu da se tržište ne optereti objavljivanjem informacija i da se ne ugroze interesi tržišnih učesnika, Direktiva o transparentnosti sadrži nekoliko izuzetaka u pogledu obaveze objavljivanja. Prvi izuzetak se odnosi na akcije stečene u cilju kliringa i saldiranja, ili od strane lica koje se bavi čuvanjem (i upravljanjem) hartija od vrednosti (obično kastodi banka ili trgovac hartija od vrednosti), pod uslovom da to lice može da glasa samo u skladu sa instrukcijama za glasanje. ${ }^{57}$ Drugi izuzetak se odnosi na tzv. „market mejkere" (market maker), odnosno tržišne snabdevače, čija je funkcija da obezbede stalnost trgovine - kupovinom po višim kursevima, odnosno prodajom po nižim kursevima. ${ }^{58}$ Međutim, s obzirom na to da oni to čine na komercijalnoj osnovi, odnosno da za to dobijaju kompenzaciju u vidu određenih povlastica i naknada, ovaj izuzetak je ograničen u smislu da se odnosi samo na sticanje do $5 \%$ glasačkih prava, kao i da lice ne vrši uticaj na izdavaoca na način da se meša u upravljanje ili utiče na društvo da pribavi sopstvene akcije. ${ }^{59}$ Sličan izuzetak se odnosi i na sticanje glasačkih prava od strane kreditne institucije ili investicionog društva - primenjuje se isto ograničenje sticanja od $5 \%$ i uslov da ne utiče na upravljanje društvom. Takođe, ne postoji obaveza da se obelodani sticanje ili raspolaganje ukoliko su glasačka prava stečena za svrhe stabilizacije, ukoliko to ne utiče na upravljanje. ${ }^{60}$

\section{5) POSTUPAK OBJAVLJIVANJA}

U odnosu na objavljivanje predviđena je dvostepena procedura: lice koje je dostiglo, prešlo ili palo ispod određenog praga dužno je da o tome obavesti društvo, koje potom obaveštava javnost o tome ${ }^{61}$ Obaveštenje sadrži podatke o situaciji u pogledu glasačkih prava; lancu kontrolisanih društava kroz koje se glasačka prava održavaju (ako je primenljivo); datum dostizanja ili prelaska praga i identitet akcionara, čak i ukoliko nema prava da vrši pravo glasa, i fizičkog ili pravnog lica koje ima pravo da vrši pravo glasa u ime tog lica.

Obaveštenje društvu se upućuje što je pre moguće, a najkasnije protekom četiri trgovinska dana (trading days) od dana kada sazna za sticanje, otuđenje ili mogućnost ostvarivanja prava glasa, odnosno za koje je trebalo da sazna ili bude obavešten o promenama koje su nastupile na osnovu obaveštenja o broju glasova

\footnotetext{
${ }^{57}$ Ibid., čl. 9 st. 4.

${ }^{58}$ Više o tržišnim snabdevačima videti u: Nebojša Jovanović, Berzansko pravo, op. cit., str. 119.

${ }^{59}$ Direktiva o transparentnosti, čl. 9 st. 5; Paul L. Davies, Sarah Worthington, Gower Principles of Modern Company Law, op. cit., p. 882.

${ }^{60}$ Direktiva o transparentnosti, čl. 9 st. 6 a.

${ }^{61}$ Ibid., čl. 12.
} 
i kapitalu koje je izdavalac objavio na osnovu dužnosti na kraju svakog meseca kada je došlo do smanjenja ili povećanja. ${ }^{62}$ Iz ove odredbe je jasno da promene mogu nastupiti i nezavisno od volje obveznika obaveštavanja. Međutim, postoje otvorena pitanja u odnosu na to kada se smatra da je lice saznalo za te promene, čime zapravo nastupa obaveza, jer je predviđeno da obaveza nastupa i onda kada je lice moralo da sazna, pri čemu ne postoje jasni kriterijumi kada se smatra da je lice saznalo za to. ${ }^{63}$ Jedan od slučajeva kada bi se moglo smatrati da je lice saznalo jeste u situaciji kada društvo objavi da je, primera radi, došlo do takvih promena usled sticanja sopstvenih akcija. U svakom slučaju, ovde postoji prostor za različita tumačenja, što može uzrokovati probleme obvezniku prilikom procene da li je promena nastupila i da li je uopšte u obavezi da obavesti društvo o promenama.

U pogledu postupka postoji posebno pravilo za grupe društava, prema kojem je samo matično društvo dužno da uputi obaveštenje, a ne i zavisna društva. Nakon što društvo primi obaveštenje, ali ne kasnije od proteka tri dana trgovanja, izdavalac je dužan da objavi informacije iz obaveštenja. ${ }^{64}$ Dakle, u izvesnom smislu je ovde obaveza društva sekundarna, jer ono samo objavljuje informaciju koju dobija od adresata obaveze izveštavanja, te tako društvo nije u poziciji da ima uticaj na sadržaj obaveštenja, iako i ono za njega odgovara.

\section{6) SANKCIJE}

Obaveza objavljivanja pretpostavlja različite mehanizme sankcionisanja: građanskopravne, krivičnopravne i administrativne. Direktiva o transparentnosti je predvidela različite vrste odgovornosti u odnosu na objavljivanje informacija o značajnom učešću: upravnu, krivičnu i građanskopravnu. Kada je reč o administrativnim merama, pored objavljivanja kršenja obaveza, izdavanja naloga licu da prestane sa radnjom povrede, novčane kazne, predviđena je i mera sankcionisanja koja je propisana posebno za kršenje obaveze o objavljivanju značajnog učešća - gubitak prava glasa. ${ }^{65}$ Uređenje gubitka prava glasa nije razrađeno, osim što je sugerisano državama članicama da mogu predvideti da se ta sankcija primenjuje samo na najozbiljnija kršenja obaveze. Dakle, pisci Direktive o transparentnosti su se zadovoljili time da takva sankcija bude propisana, a da se primenjuje samo na ozbiljne prekršaje u skladu sa načelom efektivnosti, proporcionalnosti i potrebe da sankcije deluju odvraćajuće. ${ }^{66}$

\footnotetext{
${ }^{62}$ Direktiva o transparentnosti, čl. 9 st. 2 u vezi sa čl. 12 st. 2 tač. b i čl. 15.

${ }^{63}$ Paul L. Davies, Sarah Worthington, Gower Principles of Modern Company Law, op. cit., p. 878.

${ }^{64}$ Direktiva o transparentnosti, čl. 12.

${ }^{65}$ Ibid., čl. 28b.

${ }^{66}$ Karsten Engsig Sørensen, Mette Neville, "Suspension of the exercise of voting rights - a step towards deterrent and consistent sanctioning of EU transparency requirements", Nordic \&
} 
S obzirom na to da su države članice bile obavezne da predvide suspenziju prava glasa kao jednu od sankcija, ali da nije detaljnije uređen način kako treba da učine, razlikuju se rešenja država članica. Primera radi, u Nemačkoj se sankcija primenjuje po sili zakona, bez potrebe da nadzorni organ takvu meru izrekne ${ }^{67}$ te glasanje nakon datuma povrede nije validno, dok se na drugom kraju nalaze neke države, poput Danske, u kojoj se ta sankcija primenjuje samo u slučaju teških povreda ili ponovljenih povreda. ${ }^{68}$ Značajne razlike se javljaju u pogledu toga koji organ izriče tu meru (odnosno da li se ona primenjuje ex lege), koliko traje ta mera, pod kojim uslovima se izriče i sl. ${ }^{69}$ Iako se čini da postoji saglasnost povodom efikasnosti te sankcije, budući da je primarni cilj sticanja različitih instrumenata, o kojima je bilo reči, upravo da se putem glasanja vrši uticaj na upravljanje društvom, a ova sankcija upravo to onemogućava, ona nije često primenjivana. ${ }^{70}$ Utisak je da su nadzorni organi vrlo oprezni prilikom propisivanja te sankcije i da je posmatraju kao jednu od najtežih mera koje suštinski zadiru u prava vlasnika hartija od vrednosti.

Može se, stoga, zaključiti da zadovoljavajući nivo harmonizacije u pogledu sankcionisanja, naročito kada je reč o suspenziji prava glasa i dalje nije postignut. Čini se da razlike koje u ovom trenutku postoje među državama članicama omogućavaju samo minimalnu harmonizaciju u tom pogledu, što svakako nije mali iskorak u odnosu na stanje koje je postojalo pre izmena Direktive o transparentnosti.

European Company Law, LSN Research Paper Series No. 16-25, dostupno na adresi: https://papers.ssrn.com/sol3/papers.cfm?abstract_id=2958677, 10.4.2021, p. 3. Videti i član 28c Direktive o transparentnosti, u kojem su (indikativno) nabrojani kriterijumi koje bi nadzorni organ trebalo da ima u vidu prilikom opredeljivanja za sankciju: ozbiljnost i trajanje povrede, finansijski položaj prekršioca, korist odnosno sprečavanje smanjenja imovine, gubitke koje su usled kršenja obaveze pretrpela treća lica, prethodne povrede obaveze.

${ }^{67}$ Interesantno je da se u Direktivi ne insistira na tome da sankciju gubitka prava glasa izrekne nadzorni ili drugi nadležni organ, što je prema nekim mišljenjima upravo urađeno na insistiranje Nemačke. Christoph H. Seibt, Bernward Wollenschläger, "Revision des Europäischen Transparenzregimes: Regelungsinhalte der TRL 2013 und Umsetzungsbedarf”, op. cit., p. 545.

${ }^{68}$ Ibid., pp. 6-8. Nemački sistem se ocenjuje kao najstroži, budući da gubitak prava ne podrazumeva samo gubitak prava glasa, već i drugih prava iz akcija. Štaviše, time su obuhvaćena i prava iz akcija koja pripadaju zavisnim društvima. Rüdiger Veil, European Capital Markets Law, Hart Publishing, Oxford - Portland, 2013, p. 335.

${ }^{69}$ Karsten Engsig Sørensen, Mette Neville, "Suspension of the exercise of voting rights - a step towards deterrent and consistent sanctioning of EU transparency requirements", op. cit., pp. 1-21.

${ }^{70}$ Ibid., op. cit., p. 3. 


\section{7) ZAKLJUČAK}

Izmenama Direktive o transparentnosti obaveza izveštavanja o značajnom učešću veoma je unapređena u odnosu na stanje pre izmena. Na prvom mestu, izraženo je nastojanje da se odgovori na potrebu identifikacije lica koja mogu vršiti uticaj na odlučivanje u društvu. Vodeći se tim ciljem predviđen je znatno širi domen primene, i sada je mnogo jasnije da se teži tome da se i drugi finansijski instrumenti, koji mogu imati sličan efekat kao akcije s pravom glasa, obuhvate tim pravilima. Možda se upravo tu vidi najznačajniji doprinos izmena Direktive o transparentnosti, jer je na taj način pokušano da se razreši problem tzv. „praznog glasanja", skrivenog vlasništva, sprečavanja insajderske trgovine i efikasnijeg nadzora nad tržištem korporativne kontrole (iako za poslednja dva postoje posebni izvori, Direktiva o transparentnosti može biti od pomoći).

Iako je nivo harmonizacije u pojedinim pitanjima zadovoljavajući, postoji potreba da se neka pitanja dodatno razjasne. U radu je ukazano na to da je potrebno konstantno praćenje razvoja finansijskih instrumenata (drugim rečima, ono što smo nazivali finansijska inovativnost) kako bi transparentnost bila na zadovoljavajućem nivou. Pritom, upozorili smo na to da bi trebalo biti oprezan prilikom propisivanja obaveze, jer prečesto izveštavanje može da bude kontraproduktivno. Drugo važno pitanje, koje zahteva dalju razradu, jeste uspostavljanje adekvatnih mehanizama sankcionisanja. Ipak, to ne znači da doprinos Direktive o transparentnosti, naročito u ovom pitanju, nije veliki, već samo da postoji prostor da se neke odredbe dalje razrade i preciziraju.

\section{8) LITERATURA}

Böckli, Peter et al., "Shareholder Engagement and Identification", available at SSRN. Conac, Pierre-Henri, "Cash-Settled Derivatives as a Takeover Instrument and the Reform of the EU Transparency Directive", in Hanne S. Birkmose, Mette Neville, Karsten Engsig Sørensen (eds.), The European Financial Market in Transition, Kluwer Law International BV, 2012.

Davies, Paul L., Worthington Sarah, Gower Principles of Modern Company Law, Sweet \& Maxwell, Thomson Reuters, London, 2016.

Engsig Sørensen, Karsten, Neville, Mette, "Suspension of the exercise of voting rights - a step towards deterrent and consistent sanctioning of EU transparency requirements", Nordic \& European Company Law, LSN Research Paper Series No. 16-25.

Enriques, Luca, Gargantini, Matteo, Novembre, Valerio, "Mandatory and Contractbased Shareholding Disclosure", Uniform Law Review, pp. 713-742, 2011.

Fleischer, Holger, Ulrich Schmolke, Klaus, "The Reform of the Transparency Directive: Minimum or Full Harmonisation of Ownership Disclosure", European Business Organization Law Review, Nr. 1/2011. 
Grundmann, Stefan, European Company Law: Organization, Finance and Capital Markets, Intersentia, Cambridge-Antwerp-Portland, 2016.

Jevremović Petrović, Tatjana, „Obavezno objavljivanje kao instrument zaštite poverilaca u kompanijskom pravu", Pravo i privreda, br. 4-6/2011.

Jevremović Petrović Tatjana, „Poverioci u kompanijskom pravu i instrumenti njihove zaštite", Anali Pravnog fakulteta u Beogradu, br. 1/2011.

Jevremović Petrović, Tatjana, Grupe privrednih društava, Pravni fakultet Univerziteta u Beogradu, Beograd, 2014.

Jovanović, Nebojša, „Novi zakonodavni 'mućak' Srbije u MiFID okruženju”, Vuk Radović (ur.), Usklađivanje poslovnog prava Srbije sa pravom Evropske unije (2011), Pravni fakultet Univerziteta u Beogradu, Beograd, 2011, str. 228-304.

Jovanović, Nebojša, Berzansko pravo, Pravni fakultet Univerziteta u Beogradu, Beograd, 2009.

Knuts, Marten, "The Disclosure of Cash Settled Equity Derivatives. Will the Proposed Amendments Solve the Problems", in Holger Fleischer, Jesper Lau Hansen, Wolf-Georg Ringe (eds.), German and Nordic Perspectives on Company Law and Capital Markets Law, Mohr Siebeck, Tübingen, 2015.

Lepetić, Jelena, „Aktivizam akcionara”, Pravo i privreda, br. 10-12/2018.

Lepetić, Jelena, „Jedinstvo članskih prava i ugovori o glasanju akcionara”, Pravo $i$ privreda, br. 4-6/2019.

Moloney, Niamh, EU Securities and Financial Markets Regulation, Oxford, Oxford University Press, 2014.

Osterloh-Konrad, Christine, "Gefährdet 'Empty Voting' die Willensbildung in der Aktiengesellschaft? Überlegungen zur Proportionalität zwischen Stimmrechtseinfluss und wirtschaftlicher Betroffenheit der Aktionäre", ZGR, Nr. $1 / 2012$.

Radović, Mirjana, „Zakoniti imalac dematerijalizovanih hartija od vrednosti”, Pravo i privreda, br. 4-6/2011.

Radović, Vuk, „Nejedinstven pojam zajedničkog delovanja”, Vuk Radović (ur.), Usklađivanje poslovnog prava Srbije sa pravom Evropske unije (2019), Pravni fakultet Univerziteta u Beogradu, Beograd, 2019.

Radović, Vuk, Mere odbrane akcionarskog društva od preuzimanja kontrole, doktorska disertacija, Pravni fakultet Univerziteta u Beogradu, Beograd, 2007.

Schouten, Michael C., "The Case for Mandatory Ownership Disclosure", Stanford Journal of Law, Business, and Finance, Vol. 15, pp. 127-182, 2010.

Seibt, Christoph H., Wollenschläger Bernward, "Revision des Europäischen Transparenzregimes: Regelungsinhalte der TRL 2013 und Umsetzungsbedarf", ZIP, Nr. $12 / 2014$. 
Sergakis, Konstantinos, The Law of Capital Markets in the EU: Disclosure and Enforcement, Palgrave, London, 2018.

Vanneste, Klaas, "Decoupling Economic Rights from Voting Rights: A Threat to the Traditional Corporate Governance Paradigm", European Business Organization Law Review, Nr. 1/2014.

Veil, Rüdiger, "The Reform of the Transparency Regime in European Capital Markets Laws", European Company and Financial Law review, Vol. 10, Nr. $1 / 2013$.

Veil, Rüdiger, European Capital Markets Law, Hart Publishing, Oxford - Portland, 2013.

Veil, Rüdiger, Ruckes, Martin, Limbach, Peter, Doumet, Markus, “Today's or Yesterday's News? Eine empirische Analyse von Stimmrechtsmitteilungen gemäß §§ $21 \mathrm{ff}$ WpHG und Schlussfolgerungen für die Kapitalmarktregulierung", ZGR, Nr. 5/2015.

\section{NOTIFICATION OF THE ACQUISITION OR DISPOSAL OF MAJOR SHAREHOLDINGS}

Summary: The author deals with the notification of the acquisition or disposal of major shareholdings. The provisions of the Transparency Directives and the current course of harmonization in this area have been analysed. In particular, the issues of the occurrence of reporting and the need to take into account various financial instruments and transactions that can have an impact on the management of the company without directly acquiring the right to vote are taken into account when regulating the occurrence of notification of reaching, crossing or falling below the relevant participation threshold. The existing concerns and problems that arise in connection with the existing solutions are pointed out. It was pointed out that there is a need for regulators to constantly keep in mind the innovation in the financial market in order to adequately respond to the need to identify those individuals who can really influence the decision-making of a company. However, getting the right amount of information is crucial, as otherwise market participants will be "overloaded" with information. Furthermore, there is room for improvement in terms of sanctioning failure to notify the acquisition or disposal of major shareholdings.

Keywords: major shareholding, financial instruments, acquisition or disposal of a major shareholding, disclosure of information, empty voting, hidden ownership. 